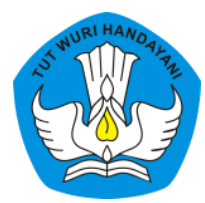

Page: 201-224

\title{
TEKNIK MOTHER BERBANTUAN CHANNEL YOUTUBE UNTUK MENINGKATKAN KEMAMPUAN SISWA MENULIS KONJUNGSI KAUSALITAS
}

\author{
Nyakmat \\ Sekolah Menengah Pertama Negeri 3 Pati, Jawa Tengah, Indonesia \\ Contributor Email: nyakmatmpd@gmail.com
}

Received: Feb 8, 2021

Accepted: Mar 6, 2021

Published: Mar 30, 2021

Article Url: $\underline{\text { https://ojsdikdas.kemdikbud.go.id/index.php/didaktika/article/view/251 }}$

\begin{abstract}
It is hoped that this research on learning the Mother technique assisted by YouTube channels is expected to be able to improve the skills of writing causality conjunctions in explanatory text and response texts of students of Sekolah Menengah Pertama Negeri 3 Pati, Central Java. The term Mother refers to two things, the first means mother while the second one from the acronym Model, Observation (observation), Write, Generate, Evaluate, and Revise. This research is a learning development research with the ADDIE model according to Dick and Carey (1996) including Analysis (analyzing student needs in writing causality conjunctions), Design (designing teaching materials using Mother's technique and validating teaching materials). Develop (development, namely testing the use of teaching materials), Implement (applying the Mother technique), and Evaluate (revising the writing of the causality conjunction of students' texts in the class which is the subject of research). The subjects of this study were two classes, namely class VIII A consisting of 32 students and class IX J totaling 27 students, so the overall subject of this study was 59 students. The results of this study showed 93\% completed in groups and $92 \%$ completed individually.
\end{abstract}

Keywords: Mother Technique; Youtube Channel; Conjunction; Causality 


\begin{abstract}
Abstrak
Penelitian pembelajaran teknik Mother berbantuan chanel YouTube ini diharapkan mampu meningkatkan keterampilan menulis konjungsi kausalitas pada teks eksplanasi dan teks tanggapan siswa Sekolah Menengah Pertama Negeri 3 Pati, Jawa Tengah. Istilah Mother mengacu pada dua hal, pertama berarti ibu sedang yang kedua dari akronim Model, Observasi, Tulis, Hasilkan, Evaluasi, dan Revisi. Penelitian ini merupakan penelitian pengembangan pembelajaran dengan model ADDIE menurut Dick dan Carey (1996) meliputi Analysis (melakukan analisis kebutuhan siswa pada penulisan konjungsi kausalitas), Design (perancangan materi ajar dengan teknik Mother dan validasi materi ajar). Develop (pengembangan yakni uji coba penggunaan materi ajar), Implement (penerapan teknik Mother), dan Evaluate (merevisi penulisan konjungsi kausalitas teks siswa di kelas yang dijadikan subjek penelitian). Subjek penelitian ini ada dua kelas yakni kelas VIII A yang terdiri atas 32 siswa serta kelas IX J sejumlah 27 siswa, jadi keseluruhan subjek penelitian ini 59 siswa. Hasil penelitian ini menunjukan 93\% tuntas secara kelompok dan 92\% tuntas secara individual.
\end{abstract}

Kata Kunci: Teknik Mother; Channel YouTube; Menulis; Konjungsi; Kausalitas

\title{
A. Pendahuluan
}

Pembelajaran menulis merupakan program konkret yang dapat digunakan untuk mengembangkan siswa menjadi pemikir kritis dan pemecah masalah, serta dapat mengembangkan keterampilan berkomunikasi (Abidin et. al., 2018: 209). Kegiatan menulis pada awalnya banyak dikembangkan di perguruan tinggi, yaitu menulis untuk menyajikan berbagai konsep perkuliahan yang sedang ditempuh. Dalam perkembangan terbaru, kemampuan literasi menulis sudah dibutuhkan siswa sejak jenjang sekolah dasar. Hal ini karena kegiatan menulis digunakan bukan hanya untuk memperlancar kemahiran teknis menulis, melainkan digunakan sarana belajar berbagai mata pelajaran. Oleh sebab itu, literasi me-nulis merupakan wujud nyata pembelajaran terintegrasi.

Dalam kaitannya dengan berbagai media yang digunakan dalam menulis, kegiatan literasi menulis menggunakan berbagai media representasi. Dalam hal ini, media yang digunakan lebih dari sekadar kertas, poster, buku, hingga teknologi seperti menulis email, menulis di blog, dan menulis di berbagai wahana online dengan jaringan internet. Hal inilah yang menyebabkan literasi menulis juga berhubungan dengan konsep multiliterasi. 
Pembelajaran menulis dalam konteks literasi merupakan aktivitas yang mendorong siswa untuk belajar. Hal ini lebih efektif dalam mengembangkan pemahaman siswa daripada sekadar membaca. Berbagai aktivitas menulis untuk menghasilkan berbagai jenis tulisan diyakini mampu memandu siswa untuk lebih fokus dalam menguasai berbagai jenis informasi. Kemampuan menulis secara analitis, lebih jauh mampu mendorong siswa untuk memahami berbagai informasi secara mendalam.

Pada pembelajaran bahasa Indonesia (yang di termasuk di dalamnya ada pembelajaran menulis) ada banyak KD yang dapat dikembangkan untuk kegiatan literasi menulis. Apalagi ada beberapa KD yang memiliki karakteristik hampir sama. Misalnya, jenis teks eksplanasi, teks tanggapan, teks eksposisi, dan teks diskusi.

Teks-teks di atas ditandai oleh sejumlah argumen penulis atau penuturnya dengan disertai fakta-fakta. Materi dalam pelajaran Bahasa Indonesia menurut Kosasih (2018) berfokus pada pengetahuan dan keterampilan tentang beragam jenis teks dengan mengintegrasikan empat unsur peristiwa berbahasa (content language integrated learning: CLIL) atau yang dikenal dengan 4C: content, cognitif, communication, culture).

Keberagaman teks tersebut juga terfokus pada kaidah-kaidah atau fiktur kebahasaan yang membentuk setiap teks. Teks eksplanasi dan teks tanggapan misalnya, masing-masing memiliki kaidah kebahasaan tersendiri. Walaupun begitu kedua teks tersebut sama-sama memanfaatkan kata penghubung atau konjungsi kausalitas atau penyebaban misalnya kata karena, sebab, menyebabkan, oleh sebab itu. Penggunaan konjungsi penyebaban tersebut perlu latihan dan bimbingan lebih lanjut, supaya siswa secara tepat menggunakannya pada kegiatan menulis teks eksplanasi dan teks tanggapan.

Keterampilan menulis teks tanggapan seperti pada penelitian yang dilakukan Sutriono Hariadi dengan judul Pengembangan Multimedia Teks Wawanrembug Berbasis Blended Learning pada Siswa Kelas VIII ditulis pada Jurnal Didaktika Pendidikan Dasar, Vol. 4, No. 1, Maret 2020, hasil multimedia teks wawanrembug berbasis blended menggunakan html, aplikasi android, dan aplikasi powerpoint layak digunakan dengan rata-rata kelas 
eksperimen 82,5 dan kelas kontrol 77,9, dengan persentase kelayakan sebesar $83 \%$. Begitu juga penelitian yang dilakukan Faiqotur Rosidah dengan judul Teknik Showing Berbantuan Multi Media Kreatif untuk Meningkatkan Keterampilan Menulis Teks Narasi. Hasil penelitiannya menunjukkan bahwa keterampilan menulis teks narasi siswa SMPN 3 Peterongan secara kelompok tuntas $97 \%$ sedangkan $95 \%$ tuntas secara Individual.

Kedua penelitian tersebut membuktikan pembelajaran bahasa perlu ditekankan pada pemakaian bahasa dalam konteks situasi, dan karena itu berbasis pada pembelajaran teks bukan sekadar didasarkan pada pandangan pembelajaran bahasa yang bersifat struktural. Pembelajaran bahasa yang berbasis teks mampu menyajikan materi yang dapat membangun struktur berpikir lengkap sesuai konteks situasinya. Baik teks yang bergenre sastra maupun teks yang bergenre faktual. Teks eksplanasi dan teks tanggapan merupakan jenis teks faktual yang banyak menggunakan konjungsi penyebaban (kausalitas). Selain kedua teks tersebut, masih ada jenis teks faktual lainnya yang menggunakan konjungsi kausalitas, namun penelitian ini fokus pada teks eksplanasi dan teks tanggapan.

Priyatni (2014:85) menjelaskan bahwa struktur kalimat teks eksplanasi menggunakan kata sambung yang menunjukkan hubungan sebab akibat (kausalitas). Konjungsi kausal adalah suatu konjungsi yang meng-hubungkan dua kata, frasa, klausa, dan kalimat yang bersifat saling memberi sebab (Sumarni, 2017). Konjungsi kausal atau konjungsi sebab merupakan konjungsi yang menjelaskan bahwa suatu peristiwa dapat terjadi karena diakibatkan oleh suatu sebab. Adapun kata-kata yang biasa digunakan pada konjungsi ini adalah sebab dan karena.

Selain itu, alasan lain yang mendasari penelitian ini adalah kemampuan siswa dalam menuliskan konjungsi kausalitas pada pembelajaran teks eksplanasi dan teks tangapan perlu mendapatkan latihan dengan bimbingan khusus supaya tulisan siswa dari kedua teks tersebut sesuai dengan kaidah kebahasaannya. Alasan-alasan inilah yang melatarbelakangi penelitian teknik pembelajaran penulisan konjungsi kausalitas ini yakni teknik Mother dengan memanfaatkan teks model untuk meningkatkan kemampuan siswa menulis konjungsi kausalitas. Teknik mother ini diilhami 
pembelajaran bahasa berbasis teks yang mampu menyajikan suatu materi yang dapat membangun struktur berpikir siswa, semakin banyak teks dikuasai siswa, akan semakin banyak struktur berpikir yang dikuasainya. Dengan topik tertentu, siswa dapat dilatih mengemukakan pandangannya tentang topik itu dalam berbagai cara (Mahsum, 2014: 99). Sejalan dengan hal tersebut, Wibowo et. al. (2021) kemampuan berpikir kritis dinilai sangat dibutuhkan oleh individu dalam kehidupannya. Sehingga guru dituntut untuk dapat mengembangkan kemampuan berpikir kritis siswa.

Istilah mother dalam penelitian ini merujuk pada dua hal: pertama, mother dalam arti harfiah berasal dari bahasa Inggris yang berarti ibu; kedua mother sebagai akronim langkah-langkah dalam pembelajaran menulis teks eksplanasi dan teks tanggapan, yaitu dimulai dengan Model, Observasi, Tulis, Hasilkan, Evaluasi, dan Revisi.

Berdasarkan latar belakang tersebut, rumusan masalah dalam penelitian ini (1) bagaimana pelaksanaan teknik Mother dalam pembelajaran menulis konjungsi kausalitas pada teks eksplanasi dan teks tanggapan di SMP Negeri 3 Pati?; dan (2) bagaimana hasil pembelajaran dengan teknik Mother dapat meningkatkan kemampuan siswa menulis konjungsi kausalitas teks eksplanasi dan teks tanggapan di SMP Negeri 3 Pati? Adapun tujuan penelitian ini adalah (1) mendeskripsikan pelaksanaan teknik Mother berbantuan channel YouTube dalam pembelajaran menu-lis konjungsi kausalitas pada teks eksplanasi dan teks tanggapan di SMP Negeri 3 Pati; serta (2) meningkatkan kemampuan siswa menulis konjungsi kausalitas pada teks eksplanasi dan teks tanggapan dengan teknik Mother berbantuan channel YouTube di SMP Negeri 3 Pati.

Hasil penelitian pembelajaran ini diharapkan dapat memberikan manfaat bagi guru, khususnya guru bahasa Indonesia, supaya pembelajaran lebih efektif, kreatif, inovatif, dan menyenangkan. Bagi siswa, penelitian ini diharapkan dapat memberikan motivasi untuk gemar menulis dan dapat meningkatkan keterampilan menulis teks eksplanasi dan teks tanggapan pada pelelajaran bahasa Indonesia khusunya, serta sebagai modal kecakapan hidup masa depannya nanti. 


\section{B. Metode}

Penelitian ini, penelitian pengembangan pembelajaran dengan desain Model ADDIE yaitu analysis, design, develop, implement, dan evaluate (Dick and Carey, 1996). Dengan langkah-langkah sebagai berikut.

\section{Tahap Analysis (Analisis)}

Langkah analysis (analisis) yaitu peneliti melakukan analisis kebutuhan. Kegiatan ini mencakup analisis kurikulum dan karakteristik siswa. Analisis kurikulum meliputi analisis kompetensi dasar (KD), analisis materi, dan analisis tujuan pembelajaran. Ketiganya merupakan kesatuan yang tidak terpisahkan.

Adapun karakteristik siswa di SMP Negeri 3 Pati dapat diuraikan sebagai berikut. (1) Jumlah siswa rata-rata per kelas 32 dengan sistem kredit semester (SKS) terdiri dari kelompok kelas 6 semester dan kelompok kelas 4 semester. (2) Sebagian besar siswa dari lulusan SD/MI yang memiliki kemampuan akademi tinggi $( \pm 70 \%)$. Hal ini disebabkan SMP Negeri 3 Pati oleh masyarakat dikategorikan sekolah favorit dan pernah dijadikan RSBI (Rintisan Sekolah Bertaraf Inter-nasional). (3) Berdasarkan survei awal ketika diminta untuk menulis paragraf bebas, 22/32 atau 78\% masih belum mampu menulis konjung-si kausalitas dengan benar dari segi kelogisan penalaran, penempatan pada kalimat (struktur), tata ejaan sesuai PUEBI, dan diksi (pemilihan kata). Selain itu, kegemaran menulis mereka belum cukup minat terbukti ketika ditanya sebagian besar ( $\pm 80 \%)$ mengaku tidak suka menulis. Penjabaran analisis kurikulum sebagai berikut. (1) Mata pelajaran Bahasa Indonesia SMP Kurikulum 2013 untuk materi teks faktual yang kaidah kebahsaan menggunakan konjungsi kausalitas teks eksplanasi, teks tanggapan, teks eksposisi, tesk ulasan, teks lapor-an percobaan, dan teks diskusi. (2) Secara umum masing-masing jenis teks faktual memiliki dua kompetensi dasar untuk KI 3 dan dua KD untuk KI 4.

Bunyi masing-masing kompetensi tersebut adalah mengidentifikasi ciri umum, dan menelaah struktur dan unsur kebahasaan teks (KI 3) serta menyimpulkan dan menyajikan teks (KI 4). Teks tanggapan deskriptif di kelas VII semester 1. Teks eksposisi di kelas VIII semester 1; teks eksplanasi 
dan teks ulasan di kelas VIII semester 2; teks laporan hasil percobaan di kelas IX semester 1; sedankan teks tanggapan dan teks diskusi di kelas IX semester 2. Teks jenis faktual tersebut mennghadirkan informasi atau gagasan dan bertujuan untuk menggambarkan, menceritakan, atau meyakinkan pembaca/penyimak. Tujuan pembelajaran umum tersebut diperinci menjadi indikator-indikator pencapaian kompetensi, untuk teks eksplanasi misalnya, indikatornya sebagai berikut. Setelah membaca model teks eksplanasi siswa dapat (1) meganalisis kaidah teks eksplanasi, (2) menganalisis polapola pengembangan teks eksplanasi, (3) membuat pola-pola pengembangan teks eksplanasi, dan (4) menulis serta memajang teks eksplanasi sesuai kerangka/pola yang telah dirancang. Indikator-indikator tersebut juga berlaku untuk pembelajaran teks tanggapan kelas IX semester 2 .

\section{Tahap Design (Perancangan)}

Langkah design (perancangan) kegiatan yang dilakukan peneliti merancang pebelajaran sesuai analisis kebutuhan yang telah diidentifikasi. Selanjutnya, peneliti mengembangkan rancangan pembelajaran menjadi draf materi ajar. Materi ajar yang dirancang dalam tahap ini masih perlu diterjemahkan agar dapat diterapkan.

Rancangan pembelajaran dimulai dari mengembangkan silabus, RPP, materi ajar, media, dan penilaian dengan kompetensi dasar menyajikan konjungsi kausalitas pada teks eksplanasi dan teks tanggapan. Karena kedua teks pada mata pelajaran bahasa Indonesia Kurikulum 2013 ada di kelas VIII dan IX semester 2, perancangan materi ajar disesuaikan pada tingkatan kedua kelas tersebut. Materi ajar diadopsi dari channel YouTube untuk dikembangan secara inovatif, yakni teknik mother berbantuan channel YouTube untuk meningkatkan kemampuan siswa menulis konjungsi pada teks eksplanasi dan teks tanggapan. Langkah-langkah pembelajaran dan tugas siswa terencana dalam buku kegiatan siswa (BKS).

\section{Tahap Develop (Pengembangan)}

Setelah rancangan materi pembelajaran dibuat, tahap berikutnya adalah pengembangan. Rancangan materi ajar yang telah dibuat pada 
tahap design tersebut menjadi model. Model tersebut sebagai karya inovasi yang digunakan dalam pembelajaran ini. Model dikonsultasikan dan didiskusikan dengan teman sejawat, baik pengurus MGMP, maupun teman sejawat yang mengajar bahasa Indonesia di SMP Negeri 3 Pati. Selain itu, peneliti berkolaborasi dengan teman-teman sejawat ter-sebut sebagai validator seperti pada tabel berikut.

Tabel 1. Validasi Model Pengembangan Pembelajaran

\begin{tabular}{|c|c|c|c|c|c|c|}
\hline $\begin{array}{l}\mathbf{N} \\
\mathbf{0}\end{array}$ & Aspek & $\begin{array}{c}\text { Validato } \\
\text { r } 1\end{array}$ & $\begin{array}{c}\text { Validator } \\
2\end{array}$ & $\begin{array}{c}\text { Validat } \\
\text { or } 3\end{array}$ & $\begin{array}{c}\text { Validat } \\
\text { or } 4\end{array}$ & $\begin{array}{l}\text { Rata- } \\
\text { Rata }\end{array}$ \\
\hline 1. & Silabus & 4 & 4 & 4 & 4 & 4 \\
\hline 2. & RPP & 4 & 4 & 4 & 4 & 4 \\
\hline 3. & Materi Ajar (BKS) & 3 & 3 & 4 & 4 & 3,5 \\
\hline \multirow[t]{6}{*}{4.} & Media & & & & & \\
\hline & Pembelajaran & 4 & 4 & 3 & 4 & 3,75 \\
\hline & 1) Channel & 3 & 4 & 4 & 4 & 3,75 \\
\hline & YouTube & 4 & 3 & 4 & 4 & 3,75 \\
\hline & 2) $\mathrm{PPT}$ & & & & & \\
\hline & 3) Google Meet & & & & & \\
\hline \multirow[t]{2}{*}{5.} & Teknik & 3 & 3 & 4 & 3 & 3,25 \\
\hline & Pembelajaran & & & & & \\
\hline 6. & Penilaian & 4 & 4 & 4 & 3 & 4 \\
\hline \multicolumn{7}{|c|}{ Keterangan: } \\
\hline \multicolumn{7}{|c|}{$4=$ sangat bagus, sangat layak digunakan } \\
\hline \multicolumn{7}{|c|}{$3=$ bagus, layak digunakan, } \\
\hline \multicolumn{7}{|c|}{$2=$ cukup, perlu direvisi, dan } \\
\hline & g, tidak layak digun & & & & & \\
\hline
\end{tabular}

Bapak Jamsir, S.Pd. sebagai validator 1 dan Bapak Moh Slamet, S.Pd., M.Pd. sebagai validator 2 pengurus MGMP bahasa Indonesia Kabupaten Pati. Sedangkan validator 3 Drs. Sarwono Sejati serta validator 4 Ibu Noor Hamidah, S.Pd. merupakan teman sejawat guru bahasa Indonesia SMP Negeri 3 Pati.

Pada tahap uji coba yang dilaksakan pada minggu ketiga Januari 2021 didapatkan hasil sebagai berikut. Pertama, berdasarkan data hasil observasi sebagian besar siswa aktif selama pembelajaran daring (28 dari 32 siswa). Kedua, respon terhadap bahan pembelajaran pun naik $80 \%$ 
baik, hanya saja menurut mereka waktu yang disediakan masih kurang. Hal ini dikarenakan peneliti menggunakan alokasi waktu lebih pendek dari rancangan yang dibuat. Hasil uji coba di kelas ini pun baik, berdasarkan nilai yang diperoleh siswa secara kelompok tuntas secara keseluruhan dan secara individu $84 \%$ telah tuntas. Kesimpulannya adalah model pengembangan pembelajaran ini layak digunakan.

\section{Tahap Implemention (Implementasi)}

Tahap berikutnya pengembangan penelitian ini adalah implementasi (implementasi). Tahap ini diimplementasikan rancangan dan metode yang telah dikembangkan pada situasi nyata di kelas. Tujuan utama tahap impementasi ini adalah (1) Membimbing siswa mencapai tujuan pembelajaran; (2) Menjamin terjadinya pemecahan masalah atau solusi untuk mengatasi kesenjangan kemampuan siswa; dan (3) menghasilkan output kompetensi menulis konjungsi kausalitas pada teks eksplanasi dan teks tanggapan. Setelah penerapan metode kemudian dilakukan evaluasi awal untuk memberi umpan balik pada penerapan model/metode berikutnya. Hal ini sesuai hasil penelitian Rukmasari (2021) yang menunjukan bahwa adaptasi teknologi TIK, termasuk berbantuan channel YouTube, yang unggul memainkan kunci penting dalam kegiatan pendidikan.

\section{Tahap Evaluation (Penilaian)}

Tahap terakhir yang dilakukan dalam penelitian ini yaitu memberi penugasan siswa untuk menulisan teks eksplanasi dan teks tanggapan dengan memperhatikan kohesi dan koherensi paragraf pada teks tersebut. Keterpautan bentuk (kohesi) maupun peterpautan makna (koherensi) dengan memaksimalkan fungsi konjungsi kausalitas pada teks siswa.

Tahap pengembangan teknik mother berbantuan channel YouTube untuk meningkatkan kemampuan siswa menulis konjungsi kausalitas dimanfaatkan pada kelas yang menjadi subjek penelitian. Kelas tersebut adalah kelas VIII A dan IX J tahun pelajaran 2020/2021. Adapun jumlah 
siswa untuk kelas VIII A sebanyak 32 siswa, sedangkan kelas IX J jumlah siswa sebanyak 27. Dengan demikian subjek penelitian ini 59 siswa yang berada di dua kelas yaitu kelas VIII A dan IX J.

Tahapan-tahapan rancangan penelitian model pembelajaran mother berbantuan channel YouTube untuk meningkatkan kemampuan siswa menulis konjungsi kausalitas seperti pada diagram 1 berikut.

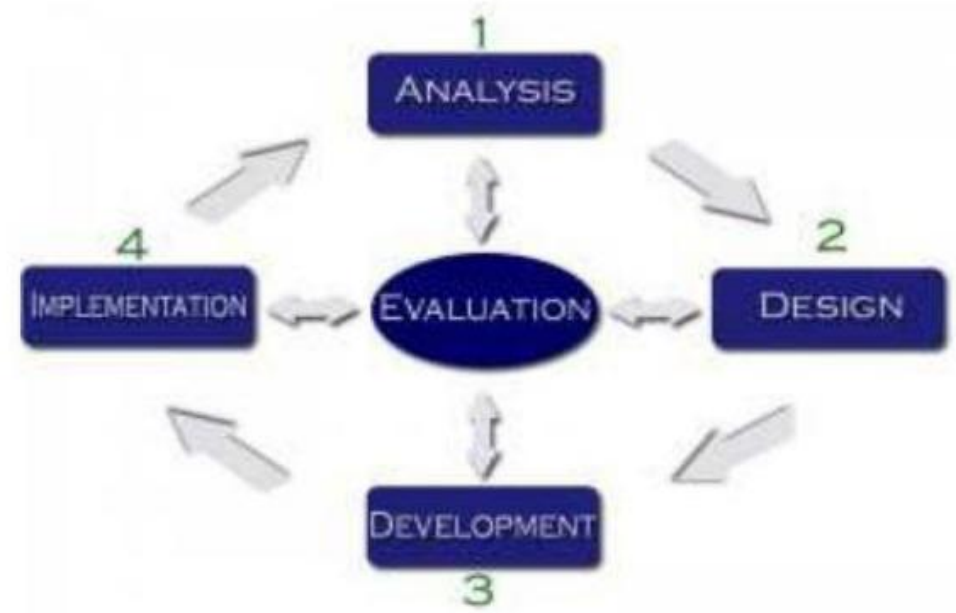

Diagram 1. Tahapan Penelitian Teknik Mother Berbantuan Channel YouTube

\section{Hasil dan Pembahasan}

Pelaksanaan pembelajaran dengan teknik Mother berbantuan channel YouTube untuk meningkatkan kemampuan siswa menulis konjungsi kausalitas kelas VIII A pada materi teks eksplanasi sedangkan kelas IX J materi teks tanggapan.

\section{Hasil}

a. Hasil Validasi Perangkat Pembelajaran

Berdasarkan hasil validasi teman sejawat sebagai validator di dapat data seperti tabel 2 berikut:

Tabel 2. Hasil Validasi Model Pengembangan Pembelajaran

\begin{tabular}{lcccccc}
\hline No. & Aspek & Validato & Validato & Validato & Validato & Rata- \\
& $\mathbf{r}$ & $\mathbf{r}$ & $\mathbf{r}$ & $\mathbf{r}$ & Rata \\
& 1 & 2 & 3 & 4 & \\
\hline
\end{tabular}




\section{Nyakmat}

\begin{tabular}{|c|c|c|c|c|c|c|}
\hline 1. & Silabus & 4 & 4 & 4 & 4 & 4 \\
\hline 2. & RPP & 4 & 4 & 4 & 4 & 4 \\
\hline 3. & Materi Ajar (BKS) & 3 & 3 & 4 & 4 & 3,5 \\
\hline \multirow[t]{4}{*}{4.} & Media Pembelajaran & & & & & \\
\hline & 4) Channel YouTube & 4 & 4 & 3 & 4 & 3,75 \\
\hline & 5) $\mathrm{PPT}$ & 3 & 4 & 4 & 4 & 3,75 \\
\hline & 6) Google Meet & 4 & 3 & 4 & 4 & 3,75 \\
\hline 5. & Teknik Pembelajaran & 3 & 3 & 4 & 3 & 3,25 \\
\hline 6. & Penilaian & 4 & 4 & 4 & 3 & 4 \\
\hline \multicolumn{7}{|c|}{ Keterangan: } \\
\hline \multicolumn{7}{|c|}{$4=$ sangat bagus, sangat layak digunakan, } \\
\hline \multicolumn{7}{|c|}{3 = bagus, layak digunakan, } \\
\hline \multicolumn{7}{|c|}{2 = cukup, perlu direvisi, dan } \\
\hline \multicolumn{7}{|c|}{$1=$ kurang, tidak layak digunakan. } \\
\hline
\end{tabular}

Berdasarkan tabel tersebut, rancangan perangkat pembelajaran untuk penelitian layak digunakan.

b. Aplikasi Praktis dalam Pembelajaran

Pembelajaran berbasis elektroknik atau E-Learning menjadi alternatif untuk mentransfer informasi secara efektif dan efisien dalam mengadopsi teknologi sebagai sarana kegiatan belajar mengajar (Arma-lina, 2020). Begitu juga pelaksanaan pembelajaran dengan teknik Mother ini memanfaatkan E-Learning yaitu dengan berbantuan channel YouTube untuk meningkatkan kemampuan siswa menulis konjungsi kausalitas dimulai pada Januari minggu pertama dan kedua di kelas VIII A dan IX J. Untuk semester genap kelas delapan teks yang kaidah kebahasaannya memanfaatkan konjungsi kausalitas adalah teks eksplanasi, sedangkan kelas sembilan teks tanggapan. Di kelas VIII A pembelajaran teks eksplanasi dilakukan dua kegiatan menyajikan teks eksplanasi mandiri dan menganalisi/menelaah kaidah kebahasaan teks eksplanasi khususnya penggunaan konjungsi kausalitas. Prosedur keduanya hampir sama, hanya beda tagihan. Jika menyajikan teks eksplanasi mandiri tagihannya berupa karya kreatif teks ekplanasi dikumpulkan pada koordinator untuk dibuatkan file WinRar melalui WAG (WhatsApp Group). Adapun kegiatan menganalisis/menelaah kaidah kebahasaan penggunaaan konjungsi kau-salitas tagihannya berupa foto hasil analisis/telaah dikirim pada Google Classroom. 
c. Menulis Teks (Eksplanasi) (9 X pertemuan, @ $2 \mathrm{JP}$ )

Sesuai dengan teknik mother yang dikembangkan peneliti, setelah apersepsi peserta didik melakukan kegiatan survei. Survei berarti membaca beberapa contoh teks eksplanasi sebagai model teks. Teks eksplanasi yang dibaca siswa minimal dua model teks yang berbeda boleh fenomena alam, sosial, ataupun budaya. Selesai membaca siswa secara kelompok untuk berdiskusi mengenai struktur dan kaidah kebahasaan yang digunakan pada teks eksplanasi model. Alokasi waktu untuk kegiatan ini satu kali pertemuan daring/dalam jaringan ( 2 X 30 menit) karena masa pandemi Covid-19. Kegiatan ini mengembangkan keterampilan collaboration dan communication pada diri siswa.

Kegiatan mengidentifikasi dan menelaah teks tahap pertama selesai. Kegiatan berikutnya, siswa menukar hasil dan mengidentifikasi perbedaan tema. Selanjutnya, siswa melakukan survei kedua untuk broswing di internet mencari teks eksplanasi dan menandai cirinya dengan menuliskan hasilnya pada buku tugas. Guru dengan kolaborator menyediakan media WAG untuk mengi-rim hasil kerja mereka untuk ditanggapi teman lainnya. Keterampilan yang dikembangkan pada tahap ini adalah critical thinking.

Survei ketiga dilakukan dengan menyaksikan tayangan dari channel YouTube serta mengikuti bimbingan guru sebagai fasilitator. Kegiatan dimulai dengan penayangan video dari channel YouTube. Siswa merancang kerangka teks eksplanasi dari tayangan tersebut dengan memperhatikan struktur dan kaidah kebahasaan seperti pada teks eksplanasi model. Dengan menemukan sendiri, sesuai penelitian Rosmarie (2021) akan membangkitkan siswa mengikuti pembelajaran, mereka menjadi aktif dalam proses pembelajaran, serta nilai mereka lebih baik daripada saat pre-test.

Pada tahap model, siswa merencanakan projek pembuatan teks eksplanasinya. Dimulai dengan penentuan fenomena alam, sosial, atau budaya yang akan dibuat kerangka teks eksplanasi sampai mengembang- 
kan kerangka tersebut menjadi teks eksplanasi yang kohesif dan koheren. Dalam kegiatan ini siswa memanfaatkan metakognitifnya ketika melakukan pembelajaran pada tahap survei. Teknologi pembelajaran sangat menaruh perhatian terhadap upaya menjadikan pembelajaran lebih efektif dan efisien melalui penerapan prinsip-prinsip yang teridentifikasi (Sari, 2020).

Tulis dan hasilkan, yaitu tahapan saat siswa berlatih menulis langsung untuk menghasilkan teks eksplanasi yang layak untuk dibaca. Pada tahap ini siswa berlatih dalam membuat kalimat serta paragraf yang kohesif dan koheren. Melalui contoh-contoh dan latihan-latihan membuat kalimat dan paragraf pada tahap tulis dan hasilkan ini diharapkan kulaitas menulis siswa terasah dengan baik.

Setelah berlatih tulis dan hasilkan, tahap selanjutnya adalah evaluasi. Kegiatan yang siswa lakukan adalah melakukan penilaian dari tulisan yang telah dihasilkan tadi. Siswa menilai dengan cermat struktur serta kaidah kebahasaan teks eksplanasi yang ditulisnya. Kegiatan-kegiatan tersebut merupakan pengembangan keterampilan berkreativitas dan menilai atau creativity and evaluation.

Pada tahap revisi, siswa diharapkan dapat membenahi teks eksplanasi yang mereka tulis. Dari hasil analisis diri penulis sendiri maupun masukan dari teman jika masukan tersebut menurut penulis layak diterima. Tetapi masukan teman jika menurut penulis tidak layak diterima sebagai pertimbangan, cukup dijadikan catatan atau arsip penulis.

Setelah kegiatan model, observasi, tulis, hasilkan, evaluasi, dan revisi, siswa menulis teks eksplanasi individunya. Tugas mandiri ini lebih banyak mereka lakukan di luar jam pembelajaran daring. Siswa dapat mengonsultasikan tugasnya ketika jam pelajaran atau di luar jam pelajaran di sela-sela waktu yang tidak mengganggu pembelajaran kelas lain.

Alokasi waktu mulai kegiatan model sampai revisi adalah empat kali pertemuan atau delapan jam pelajaran. Akan tetapi, siswa juga membutuhkan banyak waktu di luar jam pelajaran untuk menyelesaikan tugasnya dan hasil akhir karya mereka pun dibukukan (ISBN). Dengan 
demikian, pengembangan keterampilan 4C (communiation, collaboration, critical thinking, and creativity) sebagai syarat penguasaan keterampilan abab XXI dapat terlaksana dalam pembelajaran dengan teknik mother berbantuan channel YouTube ini.

\section{d. Data Hasil Aplikasi Praktis}

Berdasarkan rubrik penilaian didapatkan data hasil pembelajaran menulis konjungsi kausalitas dengan teknik Mother seperti pada tabel berikut:

Tabel 3. Data Hasil Penilaian Kelompok

\begin{tabular}{|c|c|c|c|c|}
\hline No. & Kelas & Jenis Teks & Hasil & Keterangan \\
\hline 1. & $\begin{array}{l}\text { VIII } \\
\text { A }\end{array}$ & $\begin{array}{l}\text { Teks } \\
\text { Eksplanasi }\end{array}$ & 8 kelompok tuntas & Jumlah kelompok 8 \\
\hline 2. & IX J & $\begin{array}{l}\text { Teks } \\
\text { Tanggapan }\end{array}$ & $\begin{array}{l}5 \text { dari } 6 \text { kelompok } \\
\text { tuntas }\end{array}$ & $\begin{array}{l}1 \text { kelompok belum } \\
\text { tuntas }\end{array}$ \\
\hline
\end{tabular}

Tabel 4. Data Hasil Penilaian Mandiri

\begin{tabular}{cllll}
\hline No. & Kelas & Jenis Teks & \multicolumn{1}{c}{ Hasil } & \multicolumn{1}{c}{ Keterangan } \\
\hline 1. & VIII & Teks & 30 siswa dari 32 siswa & Ada 2 siswa yang belum \\
& A & Eksplanasi & tuntas & tuntas \\
2. & IX J & Teks & $\begin{array}{l}24 \text { siswa dari 27 siswa } \\
\text { tuntas }\end{array}$ & $\begin{array}{l}\text { Ada } 3 \text { siswa yang belum } \\
\text { tuntas }\end{array}$ \\
\hline
\end{tabular}

e. Data Hasil Pengamatan

Penilaian proses menjadi salah satu bagian bahan penilaian autentik bagi guru. Penilaian proses didasarkan pada indikator pencapaian kompetensi yang belum tercaver pada penilaian hasil serta penilaian sikap yang dikembangkan selama pembelajaran. Proses siswa menulis konjungsi kausalitas pada teks eksplanasi dan teks tanggapan mulai dari melakukan survei model bacaan sampai merevisi karyanya. Indikator atau rubrik penilaiannya sebagai berikut:

Tabel 5. Ceklis (V) Penilaian Proses

Nama Siswa :

Nomor :

\begin{tabular}{cccccc}
\hline No. & Aspek/Kegiatan & & Indikator & Ya/Tdk. & Ket. (1/0) \\
\hline 1. & Model teks & $\begin{array}{l}\text { Membaca } \\
\text { saksama }\end{array}$ & serta model dengan & & \\
\hline
\end{tabular}




\begin{tabular}{|c|c|c|}
\hline & & tanyaannya. \\
\hline 2. & Observasi & $\begin{array}{l}\text { Menelaah struktur dan kai-dah } \\
\text { kebahasaan teks model. }\end{array}$ \\
\hline 3. & Tulis & $\begin{array}{l}\text { Menulis kerangka / rancang-an } \\
\text { teks yang akan dijadikan teks } \\
\text { lengkap. }\end{array}$ \\
\hline 4. & Hasilkan & $\begin{array}{l}\text { Mengembangkan kerangka/ } \\
\text { rancangan teks menjadi teks utuh } \\
\text { sesuai truktur dan kai-dah } \\
\text { kebahasaan. }\end{array}$ \\
\hline 5. & Evaluasi & $\begin{array}{l}\text { Menelaah teks eksplanasi/ } \\
\text { tanggapan serta memberi tanda } \\
\text { untuk direvisi. }\end{array}$ \\
\hline 6. & Revisi & $\begin{array}{l}\text { Merevisi dari hasil evaluasi } \\
\text { yang dilakukan sendiri maupun } \\
\text { hasil evaluasi teman. }\end{array}$ \\
\hline
\end{tabular}

Berdasarkan pengamatan mengenai tahapan pembelajaran di atas, hampir keseluruhan siswa melaksanakan tahap-tahap pembelajaran, hanya tiga siswa di kelas VIII A dan dua siswa di kelas IX J yang kurang semangat/antusias karena faktor internal mereka. Akses internet mereka kurang mendukung karena beberapa alasan yaitu faktor cuaca disebabkan Januari musin penghujan, kuota data yang habis karena belum pasang wifi di rumah, serta smartphone atau laptop mereka yang kurang memadai pada microphone atau kameranya.

f. Analisis Data Hasil Aplikasi Praktis

Data hasil aplikasi praktis pembelajaran dengan teknik Mother berbantuan channel YouTube untuk meningkatkan kemampuan siswa menulis konjungsi kausalitas analisisnya sebagai berikut.

Pertama, hasil pengamatan pembelajaran yang dilakukan guru dan kolaborator menunjukkan bahwa $100 \%$ pembelajaran terlaksana sesuai lembar pemngamatan dengan indikator pengamatan kegiatan pendahuluan, ini, sampai penutup sesuai tabel berikut ini.

Tabel 6. Ceklis Kriteria Keterlaksanaan KBM

\begin{tabular}{|c|c|c|}
\hline \multirow[t]{2}{*}{ No. } & \multirow[t]{2}{*}{ Kriteria Keterlaksanaan KBM } & Terlaksana \\
\hline & & Tidak \\
\hline 1. & Pendahuluan & \\
\hline & 1. Memotivasi siswa pada kegiatan apersepsi. & $\sqrt{ }$ \\
\hline
\end{tabular}




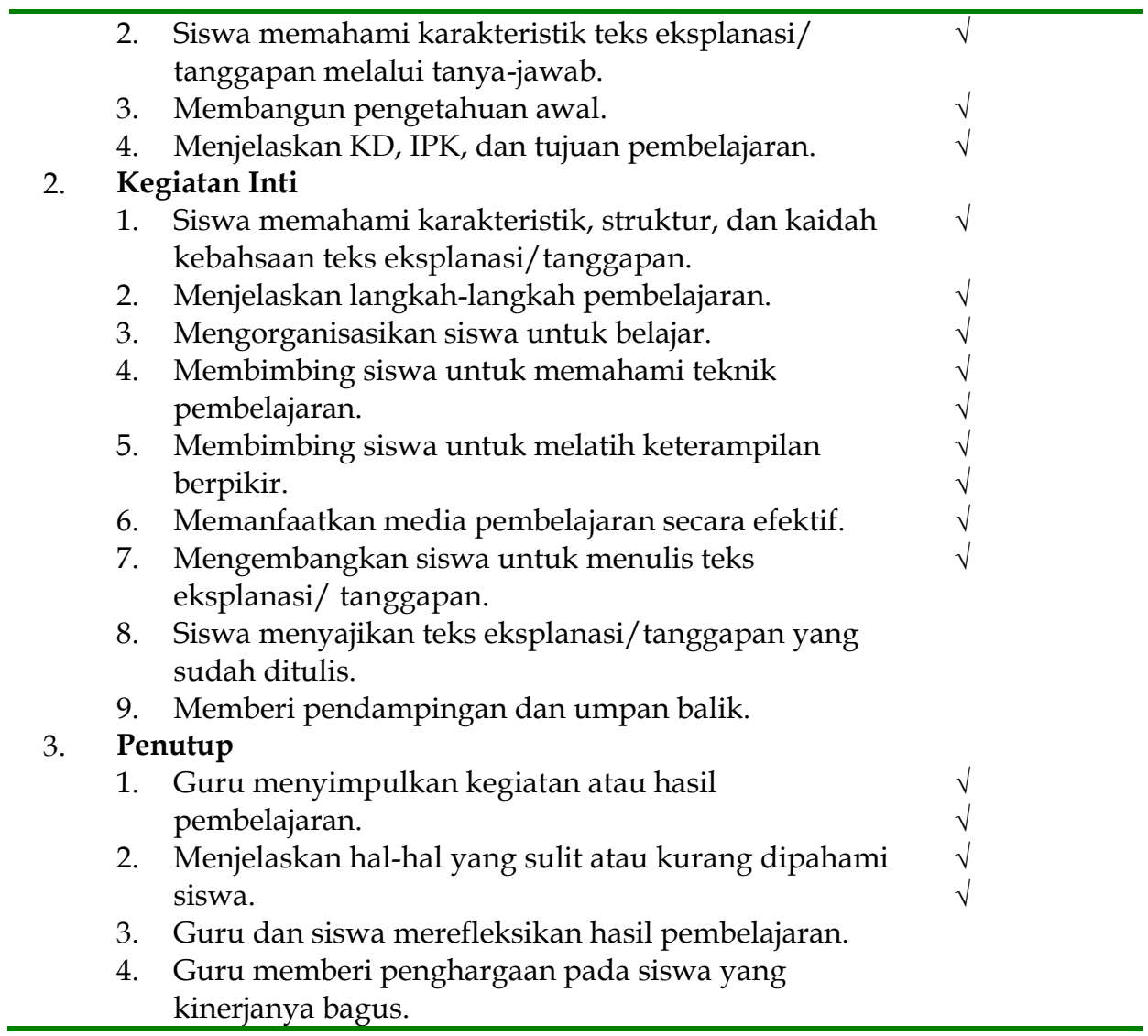

Berdasarkan tanggapan atau respon siswa terhadap pembelajaran teknik Mother berbantuan channel YouTube untuk meningkatkan kemampuan siswa menulis konjungsi kausalitas sesuai tabel 7 di bawah ini didapatkan hasil (1) 100\% mengaku menyukai teknik pembelajaran Mother, memudahkan menulis konjungsi kausalitas pada teks eksplanasi/ tanggapan dan meningkatkan kemampuan menulis mereka; (2) 100\% buku kerja siswa mudah dipahami tetapi hanya 93\% (55/59 siswa) yang mengaku bahwa BKS mudah dikerjakan; (3) 100\% guru memberikan arahan dan pendampingan kelompok tetapi hanya 88\% (52/59 siswa) yang mengaku mendapat pendampingan individual; (4) hanya 76\% (45/59 siswa) merasa waktu pembelajaran masih kurang; dan (5) sebanyak 95\% (56/59 siswa) menyatakan bahwa pembelajaran menyenangkan bagi mereka. 
Nyakmat

Tabel 7. Tanggapan terhadap Teknik Pembelajaran

\begin{tabular}{|c|c|c|c|c|}
\hline \multicolumn{2}{|r|}{ 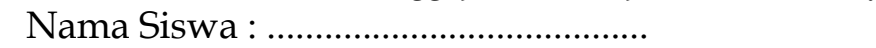 } & \multicolumn{3}{|c|}{ Nomor : ............ } \\
\hline \multirow[t]{2}{*}{ No. } & \multirow[t]{2}{*}{ Aspek } & \multicolumn{2}{|c|}{ Pilihan } & \multirow[t]{2}{*}{ Ket. } \\
\hline & & $\mathrm{Ya}$ & $\begin{array}{c}\text { Tida } \\
\mathrm{k}\end{array}$ & \\
\hline 1. & $\begin{array}{l}\text { Saya menyukai teknik pembelajaran yang dilakukan } \\
\text { guru. }\end{array}$ & $\sqrt{ }$ & & $\begin{array}{c}100 \\
\%\end{array}$ \\
\hline 2. & $\begin{array}{l}\text { Teknik pembelajarannya memudahkan saya dalam } \\
\text { menulis konjungsi kausalitas. }\end{array}$ & $\sqrt{ }$ & & $\begin{array}{c}100 \\
\%\end{array}$ \\
\hline 3. & $\begin{array}{l}\text { Teknik pembelajaran tersebut meningkatkan } \\
\text { kemampuan menulis saya. }\end{array}$ & $\sqrt{ }$ & & $\begin{array}{c}100 \\
\%\end{array}$ \\
\hline 4. & Buku kerja siswa (BKS) mudah dipahami. & $\sqrt{ }$ & & $\begin{array}{c}100 \\
\%\end{array}$ \\
\hline 5. & BKS-nya mudah dikerjakan. & $\sqrt{ }$ & & $93 \%$ \\
\hline 6. & Guru memberikan arahan jelas. & $\sqrt{ }$ & & $\begin{array}{c}100 \\
\%\end{array}$ \\
\hline 7. & endampingan kelompok. & $\sqrt{ }$ & & $88 \%$ \\
\hline 8. & Guru memberikan pendampingan Individual. & $\sqrt{ }$ & & $88 \%$ \\
\hline 9. & $\begin{array}{l}\text { Waktu pembelajaran yang diberikan guru } \\
\text { mencukupi. }\end{array}$ & $\sqrt{ }$ & & $76 \%$ \\
\hline 10. & Pembelajarannya menyenangkan. & $\sqrt{ }$ & & $95 \%$ \\
\hline
\end{tabular}

\section{Pembahasan}

Proses berpikir kausal menyatakan bahwa suatu sebab tertentu akan mencakup sebuah akibat yang sebanding, atau sebuah akibat tertentu akan mencakup sebuah pula sebab yang sebanding (Keraf, 2007: 110). Kausal sebagai pola pengembangan pada teks eksplanasi disusun berdasarkan hubungan sebab akibat yang ditandai oleh konjungsi sebab, karena, akibatnya, dan sejenisnya (Kosasih, 2018:114). Begitu juga pada kaidah kebahasaan teks tanggapan banyak menggunakan konjungsi penyebaban: karena, sebab, dll. (Kosasih, 2018:197). Kedua teks tersebut, baik teks eksplanasi maupun teks tanggapan, sama-sama membutuhkan konjungsi kausalitas. Dengan demikian, konjungsi kausalitas dalam penelitian ini merupakan kemampuan yang harus dimiliki siswa dalam pembelajaran menulis teks eksplanasi dan teks tanggapan. Selain itu keberhasilan penelitian ini tidak ditentukan dari hasil pembelajaran saja, melainkan proses pembelajaran juga merupakan penentu kesuksesan siswa dalam belajar menulis. Proses pembelajaran dapat diketahui 
berdasarkan hasil pengamatan, sedangkan hasil pembelajaran diketahui berda-sarkan nilai hasil karya siswa.

Berdasarkan hasil pengamatan tersebut ada beberapa hal perlu dievaluasi, antara lain (1) masih ada siswa yang kurang aktif meskipun persentasenya hanya 5\%; akan tetapi belajar adalah hak setiap siswa sehingga perlu diupayakan supaya seluruh siswa aktif; (2) masih ada siswa yang perlu pendampingan khusus karena berdasarkan tanggapan mereka ada yang merasa masih kesulitan dalam menyelesaikan BKS dan merasa belum mendapat pendampingan individual yang memadai; dan (3) perlu adanya penambahan waktu PBM karena 24\% siswa mengaku waktu belajar yang tersedia kurang mencukupi sehingga ada tugas yang dikerjakan di luar waktu PBM tersedia seperti menulis teks eksplanasi dan teks tanggapan mandiri.

Hasil pembelajaran teknik Mother berantuan channel YouTube untuk meningkatkan keterampilan menulis konjungsi kausalitas untuk menyajikan teks eksplanasi/tanggapan secara kelompok sesuai tabel 8 ada satu kelompok dari 14 kelompok yang belum tuntas dengan rata-rata nilai 88, sedangkan secara individual keberhasilan beradsarkan kriteria ketuntasan minimalnya mencapai $92 \%$ karena ada lima siswa yang perolehan nilainya kurang dari KKM. Namun demikian, nilai rata-rata individu mencapai 88.

Tabel 8. Hasil Pembelajaran dengan Teknik Mother Berbantuan Channel YouTube

\begin{tabular}{cccc}
\hline No. & Jenis Pembelajaran & Hasil & Persentase \\
\hline 1. & Kelompok (Cooperative Learning) & $\begin{array}{c}13 / 14 \\
\text { kelompok tuntas } \\
54 \text { tuntas } \\
5 \text { belum tuntas }\end{array}$ & $93 \%$ \\
2. & Mandiri / Individual & $92 \%$ \\
\hline
\end{tabular}

Bedasarkan tabel 8, keberhasilan pembelajaran dengan Teknik Mother berbantuan channel YouTube untuk meningkatkan menulis konjungsi kausalitas, secara kelompok mencapai 93\% dan secara individual mencapai 92\%. Analisis empat indikator penilaiaan pembelajaran teknik Mother berbantuan channel YouTube untuk meningkatkan kemampuan menulis konjungsi 
kausalitas pada teks eksplanasi/teks tanggapan meliputi sistematik, logis, relevansi, dan tata tulis. Keempat idikator tersebut seperti penjelasan berikut.

Indikator 1) sistematik pada penulisan deduktif yaitu siswa memanfaatkan konjungsi kausalitas untuk berpikir yang bertolak dari sesuatu yang umum (prinsip, hukum, teori, atau keyakinan) menuju hal-hal khusus. Dalam hal ini, siswa dapat memanfaatkan pada kalimat yang mengandung silogisme atau entimen. Kalimat siswa sebagai proses pena-laran yang menghubungkan dua pernyataan yang berlainan untuk menurunkan sebuah kesimpulan, siswa menggunakan contoh silogisme. Apabila silogisme siswa itu demi kepraktisan tidak digunakan secara lengkap karena pembacanya dianggap telah paham, siswa menggunakan entimen. Secara keseluruhan hasil karya siswa memenuhi indikator-indikator tersebut. Ada sebagian karya siswa (8-an siswa) yang menggunakan silogisme atau entimennya belum tepat. Sebagai contoh kutipan teks eksplanasi sebagai berikut.

Suatu masyarakat biasanya akan dilanda kemiskinan salah satunya karena keterbatasan sumber daya alam ataupun sumber modal. Ketika sumber daya alam tidak dapat diolah lagi, itulah salah satu penyebab kemiskinan. Keterbatasan sumber daya alam bisa juga karena bencana alam yang melanda suatu daerah. Selain menyebabkan keterbatasan sumber daya alam, bencana alam juga menyebabkan banyak orang kehilangan harta benda, sehingga langsung jatuh miskin. Selain itu, keterbatasan modal juga menjadi penghambat seseorang untuk berkembang. Terutama bagi mereka yang memiliki tingkat pendidikan rendah. Hal ini tentunya menjadi penyebab kemiskinan yang cukup serius (Dean Aprilia Ningsih, VIII A/10).

Paragraf tersebut memanfaatkan konjungsi kausalitas pada pernyataan keterbatasan sumber daya alam ataupun sumber modal, dihubungkan dengan pernyataan ketika sumber alam tidak dapat diolah lagi, diakhiri dengan pernyataan itulah salah satu penyebab kemiskinan. Dari tiga pernyataan tersebut, siswa memanfaatkan silogisme dengan tepat.

Indikator 2) logis pada pemnggunaan konjungsi kausalitas yaitu siswa menghindari kekurangcermatan, kecerobohan, ketidaktahuan, atau sikap emosional. Salah nalar misalnya kekeliruan atau ketiadaaan 
hubungan antara peristiwa, kasus, atau alasan dengan kesimpulannya. Kesalahnalaran ini siswa dalam menggunakan konjungsi kausalitas menghindari generalisasi sepintas (membuat generalisasi berdasarkan data yang sangat sedikit); generalisasi apriori (membuat generalisasi atas gejala atau peristiwa yang belum diuji kebenaran atau kesalahannya); serta kerancuan analogi (penggunaan analogi/perbandingan yang tidak tepat). Dari segi logis ini penggunaan konjungsi pada teks eksplanasi/ teks tanggapan sebagian besar telah terpenuhi, hanya ada empat siswa yang struktur teksnya belum tuntas. Keempat siswa ini terbagi dua anak pada teks eksplanasi dan dua anak pada teks tanggapan. Sebab itu, keempat siswa perlu diadakan remedial untuk menyelesaikan tugasnya. Setelah dilakukan remedial, hasilnya lebih baik. Sebagai contoh kutipan teks tanggapan sebagai berikut.

Penyebab kran air rusak biasanya karena tersumbat oleh kotoran atau sesuatu yang berukuran besar. Kotoran tersebut menyumbat pipa dan membuat kran rusak. Akibatnya para siswa dan guru tidak dapat mencuci tangan di kran. Selain tersumbat kotoran, kran rusak juga bisa disebabkan karena pemakaian yang kurang hati hati dan tergesa gesa. Apalagi usia atau masa pemakaian kran tersebut sudah sangat lama, menyebabkan kran sangat rentan dengan kerusakan (Pashareita Satya Susilo, IX J/24).

Paragraf tersebut memanfaatkan konjungsi kausalitas pada pernyataan penyebab kran air rusak, dihubungkan dengan pernyataan tersumbat kototoran atau sesuatu yang berukuran besar, kotoran tersebut menyumbat pipa, dan membuat kran rusak, pemakaian yang kurang hati-hati dan tergesagesa, usia pemakaian kran tersebut sudah sangat lama, diakhiri dengan pernyataan menyebabkan kran sangat rentan dengan kerusakan. Dari pernyataan-pernyataan yang ditulis, siswa telah berusaha menghindari generalisasi sepintas (membuat generalisasi berdasarkan data yang sangat sedikit); generalisasi apriori (membuat generalisasi atas gejala atau peristiwa yang belum diuji kebenaran atau kesalahannya); serta kerancuan analogi (penggunaan analogi/perbandingan yang tidak tepat). 
Indikator 3) relevansi yaitu penggunaan konjungsi kausalitas siswa harus ada bukti, peristiwa, atau alasan yang diajukan berhubungan serta menunjang kesimpulan yang dibuatnya. Siswa menghindari pengabaian persoalan, penyembunyian persoalan, ataupun kurang memahami persoalan. Secara keseluruhan sudah baik setelah menggunakan teknik Mother berbantuan Channel YouTube. Namun demikian, masih ada dua siswa di kelas VIII A yang memaksakan menyimpulkan walau kekurangpahaman persoalan yang ditulis dalam teks ekplanasinya. Sebagai contoh kutipan teks eksplanasi sebagai berikut.

Akibat dari masalah pengangguran tersebut dapat menimbulkan banyak masalah dari segi ekonomi maupun dari segi sosial. Misalnya orang yang tidak mempunyai pekerjaan tidak bisa mempunyai penghasilan dan alhasil tidak bisa memenuhi kebutuhannya. Pengangguran juga sering kali menjadi permasalahan ekonomi di negara. Karena dengan adanya masalah pengangguran, pendapatan masyarakat akan berkurang sehingga dapat menyebabkan timbulnya kemiskinan atau menurunnya kesejahteraan rakyat, akan muncul kekacauan sosial, dan masalah-masalah sosial lainnya (Marsha Anyadiva Putri Yaniar Rosyid, VIII A/22).

Paragraf tersebut memanfaatkan konjungsi kausalitas dengan relevansi yaitu penggunaan konjungsi kausalitas siswa harus ada bukti, peristiwa, atau alasan yang diajukan berhubungan serta menunjang kesimpulan yang dibuatnya. Kesimpulan karena dengan adanya masalah pengangguran, pendapatan masyarakat akan berkurang sehingga dapat menyebabkan timbulnya kemiskinan atau menurunnya kesejahteraan rakyat, akan muncul kekacauan sosial, dan masalah-masalah sosial lainnya didukung pernyataan misalnya orang yang tidak mempunyai pekerjaan tidak bisa mempunyai penghasilan dan alhasil tidak bisa memenuhi kebutuhannya dan pengangguran juga sering kali menjadi permasalahan ekonomi di negara. Dari dua pernyataan tersebut, siswa memanfaatkan relevansi dengan tepat.

Indikator 4) tata tulis konjungsi kausalitas yaitu penulisan ejaan dan tanda baca pada konjungsi kausalitas, tidak ada kesalahan ejaan atau 
kesalahan ejaan $\leq 4$, tidak ada kesalahan atau kesalahan tanda baca $\leq 4$. Pada indikator ini masih banyak siswa yang menjadi subjek penelitian ini hasil tulisan konjungsi kausalitas pada teks eksplanasi/teks tanggapan belum memenuhi karena 50\% kesalahannya ejaan dan tanda bacanya $\leq 4$. Peyebabnya adalah adanya kesalahan ketik dan ketidakpahaman aturan penggunaan ejaan dan tanda baca. Perlakuan atau treatment untuk indikator empat ini adalah dengan membelajarkan aturan penggunaan ejaan dan tanda baca yang mengacu pada PUEBI (Pedoman Umum Ejaan Bahasa Indonesia).

\section{Penutup}

Penelitian teknik Mother berbantuan channel YouTube dapat meningkatkan kemampuan siswa menulis konjungsi kausalitas di SMP Negeri 3 Pati. Hal ini ditunjukkan dari hasil penelitian ini yaitu keberhasilan baik secara kelompok maupun individu (mandiri). Secara kelompok keberhasilan 93\%. sedangkan secara individu (mandiri) mencapai 92\%.

Penelitian ini diharapkan memberi stimulus, memudahkan siswa memahami konsep, melakukan kegiatan-kegiatan pembelajaran, dan mempercepat mereka menyelesaikan tugasnya. Selain itu guru bahasa Indonesia maupun guru mata pelajaran lain untuk mengembangkan teknik Mother berbantuan channel YouTube untuk diterapkan untuk mengembangkan kompetensi siswa pada materi selain konjungsi kausalitas pada teks eksplanasi dan teks tanggapan.

Penelitian teknik Mother berbantuan channel YouTube untuk meningkatkan kemampuan siswa menulis konjungsi kausalitas dikembangkan dengan model ADDIE yaitu analysis, design, develop, implement, dan evaluate ini memberi harapan proses pembelajaran yang menyenangkan bagi siswa guna mengembangkan kompetensi menulis yang mereka miliki. Selain teknik Mother berbantuan channel YouTube, dapat dikembangkan dengan pemanfaatan aplikasi lain misalnya Power Point, Google Form, Powtoon, dan Google Meet. 
Nyakmat

\section{Ucapan Terima Kasih}

Terima kasih saya sampaikan kepada Ibu Ruqayah, S.Pd., M.Pd., Drs. Sarwono Sejati, Ibu Noor Hamidah, S.Pd. serta teman-teman validator dan kolaborator lainnya. Terima kasih pada Ayah, Ibu, Istri serta anak saya tercinta yang telah memberi motivasi dan penyemangat dalam menyelesaikan penelitian ini. Terima kasih juga pada teman-teman sejawat di SMP Negeri 3 Pati serta Pengurus MGMP Bahasa Indonesia SMP seKabupaten Pati. Guru mulia karena karya yang berguna untuk kemajuan dunia pendidikan.

\section{Daftar Referensi}

Abidin, Y., Mulyati, T., \& Yunansah, H. (2018). Pembelajaran Literasi; Strategi Meningkatkan Kemampuan Literasi Matematika, Sains, Membaca, dan Menulis. Jakarta: Bumi Akasara.

Armalina, V. \& Pamungkas, W.H. (2020). Analisis Resistance Factor dalam Penerapan Pembelajaran Berbasis Elektronik Menggunakan Pendekatan Human-Centered-Approach. Jurnal Ilmiah Matrik Universitas Mulia Balikpapan, Vol. 22 No. 3 Desember 2020. Doi:https:// doi.org/10.33557/jurnalmatrik.v22i3.1122

Dick, W., \& Carey, L. (1996). The Systematic Design of Instruction (4th ed.). New York: Harper Collins College Publishers.

Hariadi, S. (2020). Pengembangan Multimedia Teks Wawanrembug Berbasis Blended Learning pada Siswa Kelas VIII. Jurnal Didaktika Pendidikan Dasar, 4(1), 39-58. doi:10.26811/didaktika.v4i1.125

Keraf, G. (2007). Argumentasi dan Narasi. Jakarta: Gramedia Pustaka.

Kosasih, E. dan Kurniawan, E. (2018). Jenis-jenis Teks Fungsi, Struktur, dan Kaidah Kebahasaan. Bandung: Yrama Widya.

Mahsum. (2014). Teks dalam Pembelajaran Bahasa Indonesia Kurikulum 2013. Jakarta: Rajawali Pers.

Priyatni, Endah T. (2014). Desain Pembelajaran Bahasa Indonesia dalam Kurikulum 2013. Jakarta: Bumi Aksara.

Rosidah, F. (2020). Teknik Showing Berbantuan Multi Media Kreatif untuk Meningkatkan Keterampilan Menulis Teks Narasi. Jurnal Didaktika Pendidikan Dasar, 4(1), 169-192. doi:10.26811/didaktika.v4i1.161 
Rukmasari, A.N. (2021). Pembelajaran Daring: Ancaman Perusahaan EdTech pada Sekolah di Tengah Pandemi Covid-19. Jurnal Pendidikan dan Kebudayaan, Fakultas Teknik Elektronika dan Komputer Universitas Kristen Satya Wacana, Vol. 11 No. 1, Januari 2021: 30-36. doi:https://doi.org/10.24246/j.js.2021.v11.i1.p30-36

Rosmarie, A. \& Mualimin. (2021). Meningkatkan Pemahaman Membaca Teks Narasi pada Siswa SMP Advent Menggunakan Strategi Skimming. Jurnal Pendidikan dan Kebudayaan, Universitas Diponegoro, Semarang. doi:https://doi.org/1 Vol. 11 No. 1, Januari 2021: 30-36. doi:https://doi.org/10.24246/j.js.2021.v11.i1.p23-29

Sari, Bintari K. (2020). Desain Pembelajaran Model ADDIE dan Implementasinya dengan Teknik Jigsaw. Prosiding Seminar Nasional Pendidikan: Tema "Desain Pembelajaran di Era ASEAN Economic Community (AEC) untuk Pendidikan Indonesia Berkemajuan" Fakultas Keguruan dan Ilmu Pendidikan Universitas Muhammadiyah Sidoarjo. ISBN 978-602-70216-2-4

Sumarni, R. (2017). Konjungsi Bahasa Indonesia. Diakses dari: https://dosenbahasa.com/konjungsi-kausal pada Jumat 16 Januari 2021 pukul 09.30 WIB.

Wibowo, Sony A., et. al. (2021). Efektivitas Pengembangan Buku Ajar Berbasisi Nilai-Nilai Karakter Multikultural terhadap Keterampilan Berpikir Kritis Siswa. Jurnal Pendidikan dan Kebudayaan, Magister Pendidikan Dasar, Fakultas Keguruan dan Ilmu Pendidikan, Universitas Muria Kudus, Vol. 11 No. 1, Januari 2021: 3036. doi:https://doi.org/10.24246/j.js.2021.v11.i1.p54-62 